\title{
The Holocaust: Commemorated but not remembered? Post-colonial and post-traumatic perspectives on the reception of the Holocaust memory discourse in Poland
}

\section{Slawomir Kapralski ${ }^{1,2 *}$}

\author{
${ }^{1}$ Professor of Sociology, Pedagogical \\ University of Cracow, Poland \\ ${ }^{2}$ Lecturer, Centre for Social Studies/Graduate \\ School for Social Research, Polish Academy of \\ Sciences, Warsaw, Poland

\section{Correspondence} \\ Slawomir Kapralski, Pedagogical University of \\ Cracow; Centre for Social Studies/Graduate \\ School for Social Research, Polish Academy of \\ Sciences, Warsaw, Poland. \\ Email: Kapral@up.krakow.pl
}

\begin{abstract}
The argument focuses on the reception of the globalized narrative of the Holocaust in the regional memories of East-Central Europe, in particular Poland. It is argued that this narrative has not been successfully integrated into the regional memory, partly because of the narrative's own deficiencies and partly due to the specific nature of the way in which regional memories have been produced. Instead, it has contributed to the split of collective and social memories in the region as well as to further fragmentation of each of these two kinds of memory. In result we may say that in post-communist Poland the Holocaust has been commemorated on the level of official institutions, rituals of memory, and elitist discourses, but not necessarily remembered on the level of social memory. It is claimed that to understand this phenomenon we should put the remembrance and commemoration of the Holocaust in the context of the post-communist transformation, in which the memory of the Holocaust has been constructed rather than retrieved in the process of re-composition of identities that faced existential insecurity. The non-Jewish Poles, who in the 1990s experienced the structural trauma of transformation, turned to the past not to learn the truth but to strengthen the group's sense of continuity in time. In this process many of them perceived the cosmopolitan Holocaust narrative as an instrument of the economic/cultural colonization of Eastern Europe in which the historical suffering of the non-Jewish East Europeans is not properly recognized. Thus the elitist efforts to reconnect with the European discourse and to critically examine one's own identity has clashed with the mainstream's politics of mnemonic security as part of the strategy of collective immortalization that contributed to the development of antagonistic memories and deepened social cleavage.
\end{abstract}




\section{1 | INTRODUCTION}

The argument focuses on the reception of the globalized narrative of the Holocaust in the regional memories of EastCentral Europe, in particular Poland. It is argued that this narrative has not been successfully integrated into the regional memory, partly because of the narrative's own deficiencies and partly due to the specific nature of the way in which regional memories have been produced. Instead, it has contributed to the split of collective and social memories in the region as well as to further fragmentation of each of these two kinds of memory. It is claimed here that to understand this phenomenon we should put the remembrance and commemoration of the Holocaust in the context of the post-communist transformation, in which the memory of the Holocaust has been constructed rather than retrieved in the process of re-composition of identities that faced existential insecurity.

The impulse to this research has come from the second encounter with the set of more than two hundred interviews conducted in 1989-1993 among the inhabitants of small towns and villages in Southern Poland, who at that time were old enough to have autobiographical memories of their Jewish neighbors and personal recollections of their fate during the Holocaust. The author has participated in collecting that material and now is part of a team that revisits this evidence (that has never been thoroughly studied before) in a project "In the Footsteps of Memory: Strategies of Remembering the Jewish Culture in Polish Galicia," financed by the National Center of Science of the Republic of Poland. ${ }^{1}$

This peculiar experience of revisiting the empirical evidence twenty-five years after it was collected has an impact on the way the author intends to interpret it. When approached from today's perspective, the interviews constitute an entirely different message than the one we were ready to read at the time of their collection. That is because the researchers have changed. This may suggest that, correspondingly, the message sent by the interviewees twenty-five years ago could have been different from their original experience of the time of the Holocaust - because they have changed since the end of the Second World War.

This experience calls for a different concept of memory from the one of the mnéme (transmission of the past experiences into the present). The concept used in this text is rather the anámnesis: contextually conditioned recollection of the past that is instrumental for the construction or protection of our collective identities in the present and for the future (Yerushalmi, 1996: 107). In this process of recollection, images of the past are produced, in which the traces of the bygone time in the personal memories of individuals are filtrated through and transformed by the space in which we exist and the networks of communication in which we participate (Delanty, 1999: 71).

In more general terms this perspective follows the approach of Jonathan Friedman (1994: 141), according to whom "the past is always practiced in the present, not because the past imposes itself, but because subjects in the present fashion the past in the practice of their social identity... The past that affects the present is a past constructed and/or reproduced in the present." In other words, it is assumed here that when twenty-five years ago our interviewees shared with us their memories of the Holocaust, they have been in fact searching for the meaning of the past that would be useful in their contemporary (i.e. in the time of the interview) situation of elderly people facing radical post-communist transformation of their country, attempting to curtail the existential anxiety, and imagine themselves as those in control of contingency and able to maintain integrity in difficult moments (White, 1992). Their (re)creation of the past was coeval with and integrated into their constitution as subjects (Trouillot, 1995: 16).

\section{2 | THE CONCEPTUAL FRAMEWORK}

The conceptual apparatus of memory studies is notoriously vague. Therefore, without going too deeply into the interpretations of the key concepts as they are used in literature, I will suggest here a certain convention that is meant to order the field of my inquiry. I would thus conventionally assume that individuals' reminiscences of their pasts form their remembrance or recollection. When individuals communicate and discuss those recollections among themselves, their remembrance becomes social memory. When cultural frames and social institutions support (and sometimes induce or even create) certain forms of social memory (and weaken or eliminate others), then the collective memory 
of a given community emerges, one that "is based on selection and exclusion, neatly separating useful from not useful, and relevant from irrelevant memories. Hence a collective memory is necessarily a mediated memory. It is backed up by material media, symbols, and practices which have to be grafted into the hearts and minds of individuals" (Assmann, 2008: 55).

These three layers of memory can be structured in a twofold way, by two different processes that we may call two genealogies of memory. The first one is organized according to the principle of "distribution of energy" and leads from individual recollections that fuel social memory and then may become sedimented in the forms of collective memory. The second one follows the principle of "information control" and leads from institutional, collective memory that enhances certain forms of communication peculiar to social memory while marginalizing others, which decides which of the individual recollections will have a chance to become a topic of conversation and what shape they may take. The principles of "distribution of energy" and "control of information" as regulators of the two genealogies of memory have been transferred to this analysis from Talcott Parsons' system theory (Scott, 2011: 109-110).

According to Aleida Assmann (2008: 55-56), the second process, one that transforms the "ephemeral social memory into long-term collective memory," involves the "employment of events in an affectively charged and mobilizing narrative; visual and verbal signs that serve as aids of memory; institutions of learning and the dissemination of mass media; sites and monuments that present palpable relics; commemoration rites that periodically reactivate the memory and enhance collective participation." It must be stressed, though, that the efficiency of these activities depends, among others, on the strength of the individual remembrance that provides the "energy" for the whole process.

Therefore, the crucial segment of memory is the social memory, which is a place where two genealogies meet one another, and which serves as a space of encounter of the top-down and bottom-up memory work. Sometimes a battleground, sometimes an alliance of different tendencies, social memory is the central place in the process of collective remembering. To catch its complex nature, one can employ here the concept of memoryscape that refers to a material and symbolic space, in which social memory is expressed (Muzaini \& Yeoh, 2005: 345). Memoryscapes are spaces of coexistence (often uneasy) of various visions of the past. For this reason, the memoryscapes constitute an important realm of the struggle for power, understood here as the right to marginalize, exclude, or even criminalize those visions of the past that diverge from the sanctioned ideal. A memoryscape is therefore a "site of concentrated cultural practice" (Sewell, 2005: 172), in which power relations are negotiated with respect to the memory of a group and the present concerns of its members. Identity is one of the most important of such present concerns and memory is related to it as a "construction of a past...that selectively organizes events in a relation of continuity with a contemporary subject, thereby creating an appropriated representation of a life leading up to the present, that is, a life history fashioned in the act of self-definition" (Friedman, 1994: 117).

\section{3 | THE HOLOCAUST IN POLAND'S MEMORYSCAPES}

The Holocaust did not seem to be the crucial part of the recollections of the interviewees. They preferred to focus on the pre-war peaceful-in their opinion-coexistence of the two groups which, however, resembled more a social segregation of two mutually impenetrable worlds. When asked directly about their memories of the Holocaust, they were usually able to provide a lot of details regarding the persecution of the Jews in their towns and villages, sometimes with empathy, sometimes with indifference, but generally the tragic fate of the Jews was perceived by them as one of many other episodes of "the war" or "the German occupation of Poland" as they tended to conceptualize that time.

The absence of the fate of Jews as an important element in the recollections of the past by the non-Jewish Poles and in their social memory does not mean that they were not aware of the fact that their Jewish neighbors had been murdered. The non-Jewish Poles saw what happened but did not know what happen (Steinlauf, 1997); they did not comprehend what they saw as the horrific event that would form an epiphany (Denzin, 2002) transforming their ways of perception. Of course, we may say that in the 1940s or even later (Novick, 2001) not many people in the world had a clear idea of what actually happened. But here we are speaking about people who in 1940s and even a bit later should have-as eyewitnesses-much better knowledge than anybody else. 
It is argued here that even the eyewitnesses, those who lived where and when the Holocaust happened, need at least two things to account for their personal recollections and to frame them in such a way that they could pass to their descendants an adequate recollection of the event they witnessed. The first condition is a certain level of identification with the victims while the second is the possession of a more or less clear idea of what they have witnessed. These two conditions have not been met, which makes the Holocaust relatively absent from Poland's memoryscapes. The lack of identification with the victims accounts for the relative absence of their fate from the personal recollections of the witnesses whose remembrance did not sufficiently fuel the memory process. The lack of an elaborated Holocaust discourse in the post-war collective memories and the rejection of such discourse when it reached Poland in the 1990 s contributed to the marginalization of the recollections that contained adequate recognition of the Holocaust and prevented them from playing an important role in shaping Poland's social memories. The two genealogies of memory outlined earlier remain disjoined when it comes to the memory of the Holocaust in Poland.

It is a common practice to use in this context the concept of antisemitism as an explanatory tool and claim that Poles assigned the Holocaust to oblivion because they were/are antisemites. In this paper, instead of attributing antisemitism to individuals or groups, I would like to follow Wolfgang Benz (2004) idea that antisemitism is a dormant cultural code that, when activated, can be used as an expression of quite different tendencies. When activated, particularly in the period of crises, antisemitism receives much broader meaning than animosity towards Jews: it serves as a principle of reordering the universe in a meaningful way and as an instrument of communication that enables the majority to arrive at a common understanding. In antisemitic language, therefore, a group can express its need to build a sense of community through the construction of the shared frames in which its members interpret reality and try to re-establish the meaning of the world in a time of historical breakdowns and social crisis.

The intention of forwarding here the idea of antisemitism as predominantly a dormant cultural code is not to neglect the wide presence of antisemitism in the political, economic and cultural life of Poland before, during and after the Second World War as an active force that motivated people to acts of aggression against Jews, involving crimes committed on Jews by non-Jewish Poles. This is, however, relatively well-researched fact, especially recently. Therefore, instead of using the exploited and methodologically not fully satisfying explanatory model, in which antisemitism in the public sphere and individual minds explains concrete antisemitic acts of individuals and groups, this argument focuses on instances when antisemitism is enacted by people who otherwise cannot be essentialized as active and overt antisemites, although they usually are carriers of the elements of the antisemitic code. In particular, the interviews made me interested in the situations, where antisemitic views started to emerge in the course of conversation to be used by interviewees as rationalization or legitimization of the Jewish fate during the Holocaust. It may be thus argued that at least in certain situations antisemitism is not the cause of anti-Jewish violence, aggression and prejudice but, to the contrary, their consequence: it emerges as a means of justifying the fate of the Jews.

In this approach, antisemitism is dormant in a sense that people who start making use of its clichés are not active antisemites in everyday life, they rather are indifferent towards antisemites (and Jews). However, when Jews become victimized their situation demands an interpretation that gives a meaning to their oppression in terms acceptable to majority. Here antisemitism is being used as rationalization and reassurance of a moral order which confirm that evil things happen to evil people. In this way we may explain a sudden reference to antisemitic cultural motifs among those our interviewees who did not express antisemitism during the interview until the moment when they started referring to the fate of the Jews during the Holocaust. Their sense of moral order demanded to present the Jews as "deserving" of what happened to them and their murder as a "punishment" for their imagined crimes.

The idea of reconciling group's fate and moral order is basically a religious one and it does not come as surprise that it appealed to our interviewees who mostly were devoted Catholics. According to Max Weber, a classical author in the field of sociology of religion, the fate of an individual or a group "cannot be accepted as mere chance. It must be explained and thereby justified in some way. Those who are fortunate, need to know that their good fortune is not just arbitrary luck but deserved. Above all, when the fortunate compare themselves to the less fortunate they feel a strong need to justify the difference in terms of desert and justice. Hence the tendency to account for misfortune in terms of guilt and supernatural punishment" (Hamilton, 2001: 156). 
To illustrate this mechanism, I have selected few excerpts from an interview conducted in May 1991 in a small town S. in southern Poland with a man who was 70 at that time. ${ }^{2}$ In the first part of the interview, our respondent emphasized his generally good relations with Jews and respectfully commented on the historical religious precedence of Judaism, the strength of the Jewish religious beliefs and their positive impact on Jewish communal life. He also criticized antisemitic behavior of the non-Jewish inhabitants of his town, objectively noticing that a Jew had been feeling safe only within a distance of $\mathbf{3 0 0}$ meters from the main square with the Police station, and firmly opposed the belief in the so-called ritual murder of Christian children, allegedly having been committed by Jews. On the other hand, though, the respondent described Jews as "killers of Christ" (although refused to agree that all subsequent misfortunes of Jews could be presented as a divine punishment for this act of deicide; he noticed only that this view is widespread among non-Jewish Poles). He also reproduced the myth of Jews being buried in a sitting position to have a "better start" on the Day of Judgement and thus to outpace the Catholics in the run for salvation. Eventually, he tended to minimize the importance of "practical jokes" made by non-Jewish youngsters to their Jewish neighbors, which often involved elements of aggression. One can say that our respondent carried the elements of antisemitic code that had been stored in the language and perception of the world that characterized his community, but this code was in his case dormant: on the basis of the first part of the interview one cannot define him as antisemitic, neither in the traditional, religious sense, nor in in the modern, political one.

Everything changed when the conversation approached the murder of the Jews during the Second World War. Here, except of providing us with some details of the summary execution of the Jews from the ghetto in the nearby town of T. that he witnessed, the respondent focused almost entirely on the evil intentions of Jews, because of which they were, according to him, punished. For our respondent, Jews.

...collaborated with the Soviet communism. Communism actually was a Jewish product: Lenin, Marx, Engels and those other scoundrels - they all were Jews. They had been preparing the annihilation of the Catholics...

Our respondent understood the annihilation of Catholic Poles literally and even developed an absolutely fantastic vision of death camps operated by Jews, in which the extermination of Poles would have been carried out. Interestingly enough, in this vision he merged his own recollections of the mass execution of Jews that he had witnessed with his knowledge about death camps in which Jews were murdered, projecting, therefore, the fate of the Jews onto the Poles and blaming the Jews as perpetrators.

According to the respondent, the Jews in Poland had been.

...one hundred percent sure that communism will come from there [Soviet Union - SK] and that they all will be policemen, judges, prosecutors, that they will rule...

This image of the powerful Jews has been subsequently projected by the respondent on the pre-war reality which was combined with a perception of the Nazi murderous policy as a protective measure against the alleged Jewish domination:

[Before the war-SK] Jews had in their hands the whole trade and industry; doctors, dentists, good tailors... they all were Jewish, absolutely all. And they would not allow a Catholic in those businesses! A Catholic would not afford that in the first place and, secondly, they [Jews-SK] would not give him an access, they were so strongly organized that controlled everything, and with a purpose to destroy the Catholics. And Hitler realized that quickly and eliminated Jews, first in Germany and then in the whole Central Europe.

Then the respondent projected this image again, this time onto the present-day (at that time) reality of Poland, and claimed that even now (means in the 1990s)

Jews are in the government, eighty percent...In the parliament, senate, government...only Wałęsa is impeccable and all other are Jews... according to my peasant's perception. Well, maybe not all but more than a half are Jewish. They converted [to Christianity-SK] because they saw a good business... 
This sudden outburst of antisemitic beliefs and expressions offers a good illustration of the awakening of a dormant cultural code, triggered by the recollection of the Holocaust, the event that has been for the respondent epistemologically uncomfortable and demanded rationalization.

Antisemitism had not played any role in the previous sections of the interview (although the respondent definitely knew the elements of the antisemitic code an thus was its carrier even if he did not agree with the antisemitic, mostly religious, narratives). But having witnessing the monstrous crime that subverted moral order requires an attempt to reintroduce this order by giving meaning to the event so as to make it appear intelligible. Attribution of the guilt to the victims is a universal mechanism in such situations (Waller, 2002: 252) and because the victims were Jews, the respondent activated for this purpose the only Jewish-related cultural code that was available to him in the Polish culture - that of antisemitism.

One has, however, modify the interpretive scheme developed here and supplement it with a reflection on the particular circumstances in which respondents witnessed the murder of Jews. In the case of the interview presented here, it must be noted that the home town of the interviewee was located in the area of Poland described in Jan Grabowski's book Hunt for the Jews: Betrayal and Murder in German-Occupied Poland (2013), in which the author presented numerous instances of complicity of the non-Jewish Poles in the murder of Jews who sought refuge in the countryside. Our interviewee never mentioned this in the interview (focusing instead of his own attempts to assist Jews) but it goes without saying that he did know perfectly well what had happened to the local Jews in 19421945 and what role their non-Jewish neighbors had played in their fate. Such memories undermined the positive self-image and demanded a symbolic counteraction that involved the presentation of the acts of violence committed by the members of one's own group as their self-defense. A universal mechanism of the attribution of the guilt to the victims is, in particular circumstances, enhanced by the defensive protection of collective identity.

This issue is connected with the status of non-Jewish Poles, including our interviewees, as witnesses of the Holocaust. The term "witnessing" that I am using in this text does not imply that I treat them simply as "bystanders" to the Holocaust, especially taking into account the ethical criticism and theoretical deconstruction of this category in contemporary literature, in particular with reference to Jan T. Gross' description of the crime committed in 1941 by the Polish inhabitants of Jedwabne on their Jewish neighbors (Ehrenreich \& Cole, 2005; Friedrich, 2005; Gross, 2001; Michlic, 2012; Törnqvist-Plewa, 2005). Generally, I follow a balanced standpoint of Tom Lawson (2010: 168) that "there is no single Polish experience of Nazi anti-Judaism, no one label-be it perpetrator, rescuer, victim, or bystander-that can be applied." But it does not remove the issue of responsibility, even for the Polish rescuers and victims, because, as Stephen L. Esquith (2013: 37) convincingly argues, "those who are morally tainted by the behavior of a group they belong to, even though they did not participate in this behavior, they are morally responsible" because they were aware of the situation.

Moreover, bystanders are not only responsible because of their failure to act to prevent what they witnessed but also because of the "benefit responsibility" - the fact they in various ways benefited from the murder of the Jews (Esquith, 2013:39). Even if we do not fully accept the idea of Götz Aly and Susanne Heim (2002) that the Holocaust may be interpreted as a consequence of a rational vision of the economic modernization of the Eastern European economy, including the transformation of the social structure, rationalization of agriculture and development of the ethnically Polish middle class that was to fill in the space left by the murdered Jews, we must agree that this was, by and large, what happened. Poles have benefited from the Holocaust as a group, regardless of their individual behavior during and after the Holocaust, and this had significant psychological consequences, including various mechanisms of repression and transference, described recently by Andrzej Leder (2014) in his important book. Those who benefited from the Holocaust by taking the place of Jews in social structure preferred to silence their memories as bringing discomfort. One way of doing so "was to repeat old antisemitic stereotypes about how Jews had always been disloyal and hostile to the Poles and Poland, and therefore did not deserve to be mourned" (Törnqvist-Plewa, 2005: 148).

Our interviewees had their recollections of the Holocaust but they did not seem to communicate about this issue too often and when they did so, in the absence of an elaborated public discourse of the Holocaust in Poland before 1989, they often employed antisemitic cultural frames. These frames would help them to reorder their post-Holocaust 
experience in a meaningful way by presenting the fate of the Jews as something they had deserved, either as the ones who crucified Jesus or as those who plot to rule the world. If we refer to the two genealogies of memory presented earlier, we shall say that regarding the memory of the Holocaust the individual remembrance, on the one hand, did not bring enough energy to the process of memory production and, on the other hand, the lack of an elaborated cultural frame of interpretation of the Holocaust made the space open for a dormant antisemitic code to be used by interviewees to give meaning to and express their experiences. It may be suggested that our interviewees resorted to this strategy of memory again in the 1990s.

\section{4 | DOMINANT PARADIGMS OF INTERPRETATION}

Currently in the Polish literature there are two significant paradigms of the interpretation of the Polish memory of the Holocaust. First, there is the ethnological approach of Alina Cała (1992), in which the memory of the Holocaust has been referred to the cultural frame of the inhabitants of Polish villages and small towns. This frame has been made by a specific configuration of the traditional, peasants' worldview and folk version of Catholicism that account for the Holocaust as an event that had its place in the sacred logic of human history and can be explained as an outcome of the participation of the Jews in the foundational event of the folk religious mythology - the Passion of Christ. Second, there is the approach of Joanna Tokarska-Bakir (2004, 2008), inspired by psychoanalysis, according to which the memory of the Holocaust is repressed and tabooed as a result of various defensive mechanisms, mythologies, and rituals of erasure that are employed in consequence of the trauma related to the fate of Jews in which Poles participated as witnesses and, sometimes, perpetrators.

These two perspectives contributed excellent interpretations but nevertheless they have their limitations. The reference to cultural frame may lead to an apodictic vision of an immutable memory determined by a stable cultural pattern of thinking peculiar to a given community, insulated, homogeneous, and related to a construct of group identity that is perceived as equally static, primordial and perennial. The reference to trauma and mechanisms of its repression has been criticized in memory studies as inadequate in the analysis of the social mechanisms that characterize collectivities, as indefinite and based on vague assumptions that resist falsification. Besides, both approaches search for the factors that determine social memory outside the present: in the traumatizing events from the past or in the patterns of culture that exist outside history. This leads to the underestimation of the present, situational contexts in which social memory emerges and to which it mainly responds.

In both perspectives Jews are perceived as a permanent and significant reference point of individual memories. In the approach of Cała it is because the cultural pattern of the groups she has studied was largely formed in relation to the Jews and their religion as the "significant other." This may be true but the problem lies in the nature of the way cultural patterns operate. Ethnological approaches often adopt an essentializing standpoint, according to which the cultural pattern is always and fully manifested in the activities of individuals who belong to the culture this pattern upholds.

But if we approach ethnological research from the perspective of the phenomenology of natural attitude, we should learn that cultural patterns mostly provide rationalizations rather than motivations. When we interview people, we should bear in mind that when they speak of their memories they often refer to the cultural pattern to provide a "because-motive" of their actions and thoughts while in fact, in the very moment of action, they could be driven by situational and contingent "in-order-to-motives," loosely coupled with the cultural pattern of their community (Schütz, 1962). Correspondingly, sociologists of memory need to understand what people really want to achieve by their acts of recall, in the time these acts are being made, rather than focus on what in the past could form people to remember the way they do.

This does not mean that cultural patterns are irrelevant but that their real role needs to be properly understood. They generally serve as a resource for the production of memory, providing tools in which memory is expressed: narrative frames in which people may want to express their visions of the past, justifications and rationalizations of their 
past deeds. But they do not fully determine the way people remember. Neither do the past events to be recalled. People do remember in the present, with reference to their present concerns and future plans. Today's Poland is therefore a place where, in consequence of events, publications, debates, polemics, and commemorative activities (and counteractivities), Jews are remembered differently than, for example, in 1990s (Forecki, 2010).

In the perspective of Tokarska-Bakir, the permanent presence of the Jews in the Polish collective consciousness is attributed to the tradition of antisemitism and the repression of memories of the witnesses, perpetrators, and all those who become passive beneficiaries of the annihilation of Poland's Jews. Thus, even if Jews are not present in the memory of persons and groups they are in fact present, because their absence is achieved by complicated techniques of repression, erasure, and silencing that have the Jews as their focus. Those who use them put a significant effort into remembering to forget about the Jews. Such processes doubtlessly characterize a large segment of society, especially among the older generation, but do not play an important role among the youngest who "forget about the Jews" spontaneously and without any effort.

But maybe also the situation of the older people, who could have their personal memories of the Jews, is more complicated. They lived in the same physical space and historical time as their Jewish neighbors, but the two groups did not share the same social space and time (Roskies \& Roskies, 1975: 45; Kapralski, 1999). Jews did not form a social community with the non-Jewish Poles, the contacts between the groups were limited to economic relations, and closer ties, friendships and social encounters were very rare among adults. Both groups formed separate worlds that existed in physical proximity but were separated by the barrier of custom, endogamy, and prejudice and their members largely ignored each other (Banasiewicz-Ossowska, 2007: 88-89). The pre-war antisemitism additionally contributed to the exclusion of Jews from the Polish national community as understood by the ethnic Poles and, consequently, from its ethical norms, including solidarity (Törnqvist-Plewa, 2005: 145).

This may suggest that Jews were irrelevant to many non-Jewish Poles and it was this lack of relevance and not repression that accounts for the absence of Jews in the memories of the older generation. If they appear in those memories, it is due to the present factors, often contingent, that characterize the period in which past is recalled, not by the features of the past itself.

I would argue, therefore, that to interpret the absence of the remembrance of the Holocaust among the non-Jewish Poles it would be appropriate to use social theory of trauma (Alexander, 2012) that assumes that memory of atrocities is not an obvious and immediate follow-up of a historical event but a result of the way in which the event is approached by a community. In other words, the recollection of violence is a social-cultural construction that reflects the way in which past events are represented in the master narratives that form the collective memory of a community: namely, as something that has threatened its collective identity. To remember a past, people need a classificatory scheme, a narrative, a concept, that would organize their personal recollections, give them a meaning, and a language in which they could be spoken of. In other words, to remember mass murder of Jews as the Holocaust one needs first of all an elaborated discourse of the Holocaust. Oren Baruch Stier (2003: 1) similarly argues that "Holocaust memory matters because it is made to matter by and through the cultural forms and institutions that mediate the Holocaust in the present day," a view echoed by Levy and Sznaider: "[f]or the Holocaust to be recognized as something unique, a discursive and political frame of reference needed to be put in place" (Levy \& Sznaider, 2006: 59).

I would therefore argue that the question "Why did the non-Jewish Poles not acknowledge that they had been witnesses of the horrifying event?" should be replaced with the following one: "Why was the master narrative of the Holocaust not put in place as the frame of interpretation of their experience and why later on, when Poles have been confronted with the Holocaust discourse, have they largely rejected it?"

\section{5 | SILENCED HOLOCAUST}

The development of the narrative of the Holocaust as the frame of reference for Poland's memory has been hindered partly because of the politics of memory of the communist regime that imposed its own vision of the Second World 
War, concurring with the Marxist concept of history, in which racially motivated genocide was a secondary phenomenon caused by an interplay of the economic forces. This vision coincided with the social promotion of the large sectors of the Polish society that filled the vacuum left by the murdered Jews and thus objectively became beneficiaries of the Holocaust who, for psychological reasons, preferred to put the veil of silence over their upward mobility (Leder, 2014). To this we shall add the relative isolation of Poland from the main cultural developments of the Western world, in consequence of which, when the awareness of the Holocaust in the West began to grow in the 1960s and early '70s (Levy \& Sznaider, 2006: 17), in Poland this memory was either repressed or expelled, often together with its bearers as for example during the state-sponsored antisemitic campaign of 1968 (Steinlauf, 1997).

The lack of the master narrative of the Holocaust to which the witnesses of the crimes committed against the Jews could refer was therefore the main reason for the absence of the Holocaust from social and collective memories. Another reason was the lack of perception that what happened to Jews affected the collective identity of the nonJewish Poles. As Alexander points out, the "Polish people have acknowledged that Jews were victims of mass murder, but they have often refused to experience their own national collective identities as being affected by the Jews' tragic fate" (Alexander, 2012: 19). This was associated with the lack of identification with the victims. To identify with the Jewish victims, the witnesses of their fate would require to see them as "represented in terms of valued qualities shared by the larger collective identity" (Alexander, 2012: 19).

The concept of identity is understood here in a way close to Paul Ricoeur's (2004) "narrative identity" that consists of the "stories about oneself" constructed out of the cultural codes, literary traditions, legends and myths, which merge facts, recollections and fiction. With the help of these stories individuals and groups give meaning to their past, present and future while sorting out the episodes of their history. The stories usually imply the existence of the Other constructed as an orientation point for what the stories present to be Us, and map out a border that in our minds separates Us from non-Us. In this way our identities consist of a dialogical interplay of similarity and difference, that defines us as similar to others in our group and different from those who belong to groups that our stories take as the point of reference (Burke, 2013). And since Jews, due to historical and cultural circumstances, have been cast in the role of the Other, the identification with their fate was difficult if not entirely impossible.

Only when the encounter with the Holocaust discourse in the 1990s started to threaten the identity of the Poles as represented in the romantic code of the Polish culture, i.e. as heroic freedom-fighters and the most victimized nation, did they include the Holocaust in their collective memory. They acknowledged the fact that mass murder of Jews was a historical event of utmost importance, but instead of showing compassion many of them projected onto Jews the negative feelings they started to experience when their identity had been questioned. It must be remembered here that according to the TNS OBOP survey of August 2009, 72 percent of respondents believed that Polish nation was the most heroic during the Second World War and 63 percent of them claimed that the Poles were the most victimized people during the war. Assistance to the persecuted Jews may serve as an example of the Polish self-perception as heroic nation. In spite of the debate raised by the publication of Jan T. Gross' Neighbors, in 2000 in Poland (English edition was published in 2001) eighty-one percent of the respondents believed that Poles helped Jews to survive the Nazi persecution while seventy-six percent claimed that Poles rarely or very rarely had been involved in handing Jews over to the Nazis (Kwiatkowski, 2010: 145).

For a certain segment of Polish society, however, the encounter with the Holocaust discourse could indeed produce a sense of compassion and identification that would simultaneously make them adequately acknowledge the fate of the Jews and revise their concept of collective identity to make it inclusive and self-critical. This segment, even if slowly growing in size is still relatively small. The Holocaust is listed as the fourth most important event of the Second World War and is well-known to fifty-three percent of the respondents in the research conducted in 2009 (Kwiatkowski, 2010: 168). In 2015, for forty-five percent of respondents the main association with the word "Auschwitz" was the "suffering of the Polish nation" (in 1995 - for thirty-two percent), while for thirty-three percent it was the "Holocaust of the Jews," compared to 18 percent in 1995 (CBOS, 2015: 6).

These results indicate that the encounter with the Holocaust discourse caused for many Poles a defensive reaction, in spite of a significant number of cultural and educational initiatives, publications and conferences, which took 
place after the collapse of communism. Most important among these developments have been changes in the school curricula and special programs addressed to teachers in the field of education about the Holocaust. In addition, a number of commemorative ceremonies with the participation of the authorities helped to focus public opinion on the previously neglected Jewish aspects of Polish history. The process of change has particularly involved the area of Auschwitz-Birkenau where the museum exhibition has been refurbished with the participation of Jewish institutions to emphasize the role of the place as the symbol of the Holocaust and to clearly indicate that it was first of all the site of mass extermination of men, women and children, sent to their deaths because they were Jewish (Weinbaum, 2001).

But as the results of the surveys presented earlier indicate, the new cultural frame for memory that has been developed in Poland since the 1990s does not contribute to the organization of popular memory and the two genealogies of memory presented in the opening parts of this article remain disjoined, which often leads to attempts to erase the most uncomfortable historical moments as not belonging to the "true" national life and to replace them with narratives of nation's glorious past (Esbenshade, 1995: 80). As a result, we may observe a split in Poland's Jewish memoryscapes with a growing number of those who opt for the critical re-examination of the national past and an equally growing number of those who prefer to defend the mythologized vision of the glorious history of the Polish nation. We may expect that the views of the second group will be further reinforced by the historical politics of the new government elected in 2015.

To search for the genesis of this split, we must go back to the 1970s-1980s that is to the forming period of anticommunist opposition. The movement, that eventually contributed to the collapse of communism and built the foundations of post-communist Poland, has been characterized by Jan Kubik (1994: 255-256) as essentially cultural, rooted in the need "to revive Polish culture,...to reconsider a fresh Polish identity and the ethical foundations of the society." As Kubik argues further, such priorities determined the discourse of the opposition, formed predominantly by the language of religion and national mythology. Such a nature of the anti-communist discourse contributed to the "dramatical polarization" of the vision of the social world, interpreted as a battlefield of the Good ("true Poles") against the Evil, represented by communists. This polarization, together with accompanying fundamentalist mentality, has continued in the 1990s, already in post-communist Poland, and became dysfunctional in a country building democratic political institutions and capitalist economy (Kubik, 1994: 257).

The side-effect of this process was the awakening of the antisemitic cultural code, present both in religion and nationalism, that was visible in the attempts to externalize the evil from the Polish national community by refreshing the myth of "Jewish communism" ("Żydokomuna") and general attribution of all pitfalls and failures of the post-communist transformation of the country to the conspiracy of Jews/communists/World Bank/Western corporations etc. In result, the critical revision of both the communist history of Poland and its popular, mythologized alternatives, attempted by liberal intellectuals in 1990s, has been met with distrust by many Poles who, following the "Us-Them" polarization, perceived it as essentially "anti-Polish."

These processes occurred in the atmosphere of instability and insecurity that was connected with social, political, and economic transformation and increased the "structural trauma," which was the response of large sectors of the post-communist society to the immense change in their lives. Such experiences, as we know, often contribute to the restructuring of memories in which those affected by the transformation process seek support rather than challenge.

The anxieties associated with the structural trauma of the present may sometimes have an impact on the "historical traumas" experienced in the past that are re-interpreted from the point of view of the present and thus contribute to the deflection of memories (LaCapra, 2001). This might be the case of our respondents in the 1990s: their anxieties of that time set in motion identity-protection mechanisms which largely ruled out the chance of self-critical historical examination and identification with the Jewish victims of the Holocaust. Instead, they preferred to recall a nostalgic image of the past (Sztompka, 2000: 284), that would bring some comfort in their present identity crisis.

Memoryscapes do have an existential dimension: an imperative to provide ontological security for individuals and groups, that is to build a sense of the continuity of the group's life and the durability of its institutions in which an individual life is embedded through various processes of routinization (Giddens, 1994: 80; 1990: 92). People 
remember not in order to record the past events (which is the task of historians) but largely "in order to seek stability and purpose in existence" (Törnqvist-Plewa, 2005: 158). While doing this, they tend to silence those episodes of history that form a threat to their feeling of security (Bauer, 2001: 40) which can be called a policy of mnemonic security that secures certain forms and contents of memory by delegitimizing or even criminalizing others (Mälksoo, 2015: 221).

This policy corresponds with the concept of memoryscape as a field of power that has been outlined earlier with reference to Sewell's (2005) idea of the sites of concentrated cultural practice. In other words, mnemonic security is a tool in a group's fight for the imagined future (to secure a sense of continuity and increase the group's survival potential) that is fought on the territory of the imagined past (Bauman, 1992: 55), with an assumption that a glorious past is a warrant for collective immortality. But as Bauman (ibid.) observes, immortality is a social relation: our group obtains it at the expense of others whose histories are erased or denied visibility as a threat to ours. This, in Bauman's terms, "differential deprivation of history" is activated in periods of crisis through the politics of mnemonic security that leads to antagonism of memories and condones the alternative visions of the past.

The two mechanisms described above: the induction of historical trauma by the structural trauma of transformation, and the politics of mnemonic security as part of the strategy of collective immortalization, jointly contributed to the antagonism of Jewish and non-Jewish memories. The non-Jewish Poles, who in the 1990s experienced the structural trauma of transformation, turned to the past not to learn the truth but to strengthen the group's sense of continuity in time. By reference to the historical trauma they survived in the time of the Nazi occupation of their country, they strengthened their ontological security and built confidence that they will survive the present rupture as well.

But while turning to the 1940s, they inevitably met in their memories the Jews whose tragic fate, according to the logic of memory process presented here, had to be erased as an obstacle on the way to the (ethnically) Polish collective immortality. Therefore, the lack of elaborated and compassionate memories of the Holocaust on the part of the non-Jewish Poles can be accounted for by the inherent logic of the memory process as an anámnesis, rather than by antisemitic cultural patterns or repression of guilt although they of course perform a role in it, for example as cultural resource out of which memories are constructed.

The encounter with the ("cosmopolitanized") discourse of the Holocaust in the 1990s, advocated by a part of the nation's intellectual and political elite, meant for many Poles an invasion of an entirely different approach to memory. Instead of the antagonistic pattern in which a group's memory serves as a resource in the process of building ontological security through marginalizing or erasing the past of other groups, they had been proposed an agonistic pattern, in which the memories of others have legitimate place within "mnemonic pluralism" that "would enable different interpretations of the past to be questioned, in place of pre-defining national or regional positions on legitimate remembrance in ontological security terms" (Mälksoo, 2015: 221).

The terms "antagonistic" and "agonistic" are employed here in a way that follows Chantal Mouffe's distinction, in which "[a]ntagonism is struggle between enemies, while agonism is struggle between adversaries." The transformation of antagonism into agonism which should be the aim of democratic politics, "requires providing channels through which collective passions will be given ways to express themselves over issues, which, while allowing enough possibility for identification, will not construct the opponent as an enemy but as an adversary" (Mouffe, 2000: 16).

A similar concept, directly in the field of memory studies, can be found in Michael Rothberg's idea of multidirectionality of memory. In his opinion, the memory and identity of a group can be and in fact are constructed without excluding memories and identities of others, in a public sphere that is not a battlefield but a discursive space, and in this process there are neither winners nor losers but rather interacting groups that borrow from one another elements of memory and identity (Rothberg, 2009: 4-6).

Yet another concept of this kind, a "polycentric" social memory, has been advocated in Richard Sennett's reinterpretation of Maurice Halbwachs' (1992) theory. This kind of memory requires the groups involved to accept that none of them is at the center of memory and that the memory process presupposes an interaction between different centers rather than the defense of the fortress of one's own memory. It is of particular importance in the case of memory work which deals with issues so painful that debating them resembles reopening wounds. This is something "people 
cannot do by themselves" but this is something they have to do in order to remember well, which "requires a social structure in which people can address others across the boundaries of difference" (Sennett, 1998: 22).

Unfortunately, almost all these ideas of mnemonic pluralism, multidirectional, and polycentric memory suffer from a rationalist illusion that people can change when persuaded. Moreover, their realization would require a fundamental rethinking of the relation between memory and group identity that would be possible on a large-scale, as much as it could be, only in a relatively safe environment where the identity of a group would not be threatened. This was not the case of Poland in the 1990s. In the end, no social structure of the kind Sennett assumed to be a precondition of the mnemonic transformation has emerged in Poland, which has resulted in the fragmentation of Poland's memoryscape that has further contributed to the polarization of Polish society. The instances of the transformation of collective memory and the official commemoration of the Holocaust, significant as they were, had been therefore framed into a dualistic antagonism of memories and have thus proved unable to contribute substantial change on the level of social memory in Poland.

It seems that a more realistic picture of the way memory works in a situation of crisis has been given by Richard Terdiman (1993: 31-38) in his outline of the nineteenth century transformation of memory. In his approach, it is precisely the reluctance towards changing the perception of the past that has social-structural grounding. People and societies who experience crisis usually reject revisions of memory to protect the stability of their social formation and often use for that purpose thinking in terms of various dichotomies that fit the antagonistic paradigm of memory. They tend to idealize their past as their own and even if Rothberg (2009: 5) is right that in reality no group can claim exclusive ownership of what it perceives to be its history, this is precisely what groups are doing and the illusions they produce are real because they organize the thought and action of their members.

\section{I COSMOPOLITAN MEMORY OF THE HOLOCAUST}

Since the end of the 1970s we have observed a process of globalization (Huyssen, 2000) or cosmopolitanization (Levy \& Sznaider, 2002) of the Holocaust discourse and memory in which the Holocaust becomes a universal pattern for any historical trauma, applicable to various instances of genocide, and reconfiguring national cultures of memory. This process has since the 1980s been accompanied by criticism of the human rights record of authoritarian regimes, among them communist regimes (Bull \& Hansen, 2015: 2).

In the 1990s the cosmopolitanized memories of the Holocaust have started to serve as a means of reorganization of the value-consensus in Western Europe after the collapse of communism and as a normative standard for the former communist countries that struggled to be included in the European system (Levy \& Sznaider, 2006). Several authors have claimed at that time that the memory of the Holocaust shall acquire a new, European, meaning to be an effective symbol of the European Union, and that the new Poland in particular should make this memory the center of reflection on the heterogeneous, pluralist and multicultural Europe, the incarnation of which Jews once were (Pinto, 1996; Tyndall, 2004).

But in the following years the discourse of the Holocaust has not turned into a reference for constructing, perceiving, and representing the imagined European community. Especially in Eastern Europe, the Holocaust as an event and as the frame of historical perception, has not found its way into the social memories (Cohen, 1999; Himka, 2008; Shafir, 2004) and is largely confined to elitist discourse and institutional rituals of remembrance.

I would argue that an important cause of the rejection of the Holocaust discourse in Poland of the 1990s was precisely its cosmopolitan nature and an analysis of this rejection may draw on the resources of postcolonial theory. After decades of living in the cultural landscape marked by political ideology and concept of history that have been perceived by many Poles as having been externally imposed and supporting the political dependency of their country, Polish society has experienced the newly encountered Holocaust discourse as part of yet another external system of cultural domination correlated with the passage of Poland into the domain of Western countries and their political and economic interests. In this context, many "postcolonial Poles" found themselves "in danger of self-colonization 
through the wholesale acceptance of Western ideas which may lead to a new dependence-on the Western construction of cultural memory" (Uffelmann, 2013: 111).

This nature of cosmopolitanism has been recognized by its exponents: Levy and Sznaider (2007) "have themselves acknowledged the risk that cosmopolitanism may be conceived and perceived as a deeply Eurocentric project, as a new form of universalism which has its roots in the Enlightenment" (Bull \& Hansen, 2015: 3). As such, cosmopolitanism may be viewed as a "core European project" for Europe's periphery, intended to mollify Eastern European nationalisms, frozen under communism, that apparently resurged with the collapse of this system (ibid.). The Holocaust memory that formed part of the cosmopolitan discourse underwent thus to an extent the process of mythologization, turning it into the supposed founding narrative of the post-Holocaust and post-communist Europe that conceals the deficiency of political identity and serves as a surrogate one (Probst, 2003).

The collapse of the communism meant, among others, the liberation of the repressed alternative Polish memories of oppression and suffering under the communist rule. Unfortunately, this reemergence of memory took place exactly in the time when the memory of the Holocaust has been instituted as the cornerstone of the European "transnational memory, providing the EU with a 'foundation myth' and a moral yardstick for new member states" (Assmann, 2013: 27). This peculiar "bad timing" caused a situation perceived by many Poles as the denial of their newly regained history whereby "the focus on the Holocaust...prevents people from investigating or taking equally seriously cases which do not appear to be exactly like it" (Stone, 2010: 28).

This asymmetry in the European memory caused a feeling, widespread in Eastern Europe, that the victims of the communist oppression have not received "a rightful place in Europe's historical memory and moral consciousness" (Assmann, 2013: 31). This sense of injustice was aggravated by the attitude and practice of the Western European public intellectuals and institutions, for whom, as in the often quoted sentence by Tony Judt (2005: 803), the recognition of the Holocaust became "a contemporary European entry ticket," and precondition of achieving the status of "truly European citizens" (Challand, 2009: 399) whereby the development of the Holocaust memory has been used to informally rank Eastern European countries applying for the participation in the European structures (Kucia, 2016: 113).

This caused a backlash in some sectors of the Polish society that perceived their situation as a passage from one form of the ideological control of memory to another, equally not allowing them to express the vision of the past they would like to call their own. Since this passage was part of the larger social, economic and political neoliberal transformation masterminded by the Western expert, the globalized discourse of the Holocaust started to be seen as an instrument of the economic/cultural colonization of Eastern Europe, in which its inhabitants were expected to adopt the cultural codes of Western Civilization with no reciprocity (Pearce, 2011: 262). For example, the attempts by Poles and other East Europeans to bring their own suffering under communism into the center of European memory were often discarded as "a thinly veiled attempt to mitigate East Europeans' own complicity in the Holocaust" (Mälksoo, 2014: 82). Needless to say, for many Poles this attitude entailed the revival of the antisemitic association of Jews with "cosmopolitanism" and anti-Polish conspiracy.

Poles (and other East Europeans), in their turn, often had a feeling that the memory of the Holocaust belongs to the category of "screen memories" that is "that the Holocaust is remembered in order to repress other instances of historical oppression that are closer to home-or simply block insight into specific local histories" (Craps \& Rothberg, 2011: 518). One of such instances of oppression screened by the Holocaust memory was precisely the suffering of East Europeans under the communism, and this screening was sometimes perceived in Eastern Europe as another thinly veiled attempt, this time to inhibit "potentially uncomfortable questions for some about West European complicity with the East European postwar plight under communist rule" (Mälksoo, 2014: 84-85).

For many Poles in the 1990s, the multidirectional character of contemporary memories, advocated by some scholars (Rothberg, 2009), turned out to be surprisingly one-directional, not taking into account their local memories and perceptions of history. But as a matter of fact the cosmopolitan narrative has been endorsed by an important sector of the Polish society, we may say, an elite, that largely contributed to the transformation of collective memory by publications, debates, film and theater productions, academic conferences, educational programs, curriculum changes, 
artistic events, museum exhibitions, and public commemorative events. The result, however, was a split of cultural frames of memory as well as a growing gap between elitist and popular discourses that contributed to the political divide and unrest.

The division of memories and discourses in question turned out to be antagonistic rather than agonistic and there is not much interaction between neo-nationalist and cosmopolitan narratives of the past, which in more general terms is "an indicator of the growing and worrying divergence between an 'exterritorial elite' and the 'settled majority'" (Bull \& Hansen, 2015: 2). In terms of Wulf Kansteiner (2002), it seems that the narrative of the Holocaust has indeed inspired an important group of "memory producers" but failed to reach "memory consumers," largely because of a lack of a mediating category that we may add to the Kansteiner's model and that we may call "memory retailers": those who would serve as a conveyor belt and translators of the elitist ideas into popular discourse.

It should be added that the Holocaust discourse suffers from its own deficiencies. It is argued that it has been threatened by an inflation of rhetoric and exaltation of memory that led to the dissolution of its actual meaning into abstraction and the convenient hypnosis that prevents us from knowing what actually is to be remembered (Hoffman, 2004). This could contribute to the perception of the acts of the Holocaust memory, especially in their public, official forms "as empty, complacent rituals that serve only to pacify the past, making it safe for the present to ignore" (Stone, 2010: 23). This is actually an unavoidable part of the construction of collective memories and its rituals: they "sanitize...the messy history lived by the actors" and "contribute to the continuous myth-making process that gives history its more definite shapes: they help to create, modify, or sanction the public meanings attached to historical events deemed worthy of mass celebration" (Trouillot, 1995: 116).

This situation constitutes thus a deadlock in which the critical potential of the Holocaust discourse is rejected by those who profess the East European version of redemptive mythology (Tismaneanu, 1998) while the discourse's own mythologization sometimes puts off those East Europeans who consider it an important vantage point in critically reflecting upon the memories and perceptions of the past in their societies.

\section{7 | CONCLUSIONS}

As Dieter Pohl (2004: 27) has observed, "there is an extensive culture of Shoah remembrance in Poland...but interest in it is, by and large, restricted to parts of liberal intelligentsia." It means that in the post-communist Poland the Holocaust has been commemorated on the level of official institutions, rituals of memory, and elitist discourses, but not necessarily remembered because the official frames are often inconsistent and, besides, do not perform well the role of organizing the social memory-for the reasons outlined in this paper.

The Holocaust has been therefore incorporated as one of the streams of Poland's collective memories. But the mechanisms of information control turned out to be weak while the energy distribution did not sufficiently fuel the memory process due to the growing time-distance and generational gap. The two genealogies of memory remain disjoined regarding the memory of the Holocaust: the individual remembrance is vanishing while the Holocaust discourse is largely rejected. The result is a vacuum on the level of social memory, filled by polarized tendencies: elitist critical re-examination of the past on the one hand and, on the other hand, popular mythologies that chase away ontological insecurity.

The individual remembrance and social memory of individuals are largely formed by the consequences of the crisis of collective identity in the 1990s that was also responsible for the activation of the antisemitic cultural code, subsequently employed as a language in which the memory of the Holocaust has been expressed in the interviews we have conducted at that time. Thus we may speak of overt silences in connection with individual memories and covert silences in connection with official frames and collective memories that do not have sufficient content to successfully organize social memories and give individuals an adequate language in which they could express their recollection (Vinitzky-Seroussi \& Teeger, 2010:1104). This may confirm a pessimistic observation of Barbara Engelking (2001: 324), based on her study of the memories of the Holocaust survivors: "Although I believe that the Poles, as the closest 
witnesses, have certain obligations, I still know that these events cannot be absorbed into Polish culture, and cannot be seen by Polish society as their own."

It seems that the memory of the Holocaust has been treated by some sectors of Polish society, mostly those affected by the trauma of transformation, as interfering with the Polish memory as the celebration of nationhood (for it has questioned both the heroism of the Poles and their self-proclaimed status as the main victims). This largely prevented the memory of the Holocaust from being included in Poland's memoryscape, in spite of noble efforts, and has divided public opinion, thus leading to the polarization of standpoints revealed by the surveys' results. The time of the transformation is ambiguous: on the one hand it offers a chance to revise what used to be perceived as taken-forgranted, but on the other hand it is not the most convenient period for a critical re-examination of the past: even if it calls for the revision of mythological views, it is usually a fraction of society that advances critical memory. For the remaining part, threatened in their ontological security, memories serve as trenches and myth as a protection. When such people share their recollections with us, we may learn from them more about their present situation than about the past they witnessed.

\section{ENDNOTES}

${ }^{1}$ It has to be noted, however, that this article is not a research report. It is a theoretical inquiry, inspired by the contact with empirical evidence, the task of which is to construct an interpretive framework in which this evidence is to be studied, hopefully better than with the use of the already existing perspectives.

2 Interview conducted on 11 May 1991 by Kamila Kalinowska. The recorded interviews collected in the research mentioned here are stored at the Institute of Sociology of the Jagiellonian University, Cracow, Poland.

\section{REFERENCES}

Alexander, J. C. (2012). Trauma. A Social Theory. Cambridge: Polity.

Assmann, A. (2008). Transformations between history and memory. Social Research, 75(1), 49-72.

Assmann, A. (2013). Europe's Divided Memory. In U. Blacker, A. Etkind, \& J. Fedor (Eds.), Memory and Theory in Eastern Europe. New York: Palgrave Macmillan.

Banasiewicz-Ossowska, E. (2007). Między dwoma światami. Żydzi w polskiej kulturze ludowej. Wrocław: Polskie Towarzystwo Ludoznawcze.

Bauer, Y. (2001). Rethinking the Holocaust. New Haven and London: Yale University Press.

Bauman, Z. (1992). Mortality, Immortality and Other Life Strategies. Cambridge: Polity Press.

Benz, W. (2004). Anti-Semitism in Europe. Traditions, Structures, Manifestations. (The Hugo Valentin Lectures III). Uppsala: Uppsala University.

Bull, A. C., \& Hansen, H. L. (2015). On agonistic memory. Memory Studies. [published before print November 27, 2015, as https:// doi.org/10.1177/1750698015615935; http://mss.sagepub.com/content/early/2015/11/26/1750698015615935.full.pdf]

Burke, P. J. (2013). Identity, Social. In B. Kaldis (Ed.), Encyclopedia of Philosophy and the Social Sciences (Vol. 1). Los Angeles: Sage.

Cała, A. (1992). Wizerunek Żyda w polskiej kulturze ludowej. Warszawa: Wydawnictwa UW.

CBOS (2015). Auschwitz-Birkenau w pamięci zbiorowej. CBOS Research Reports No. 11, January 2015.

Challand, B. (2009). 1989, contested memories and the shifting cognitive maps of Europe. European Journal of Social Theory, 12(3), 397-408.

Cohen, S. J. (1999). Politics Without a Past. The Absence of History in Postcommunist Nationalism. Durham and London: Duke University Press.

Craps, S., \& Rothberg, M. (2011). Introduction: Transcultural negotiations of Holocaust memory. Criticism, 53(4).

Delanty, G. (1999). Social Theory in A Changing World. Conceptions of Modernity. Cambridge: Polity Press.

Denzin, N. K. (2002). Interpretive Interactionism (2nd ed.). London: Sage.

Ehrenreich, R. M., \& Cole, T. (2005). The perpetrator-bystander-victim constellation: Rethinking genocidal relationships. Human Organization, 64(3), 213-224.

Engelking, B. (2001). Holocaust and Memory. In G. S. Paulson and Translated by E. Harris (Eds.). The Experience of the Holocaust and Its Consequences: An Investigation Based on Personal Narratives. London and New York: Leicester University Press. 
Esbenshade, R. S. (1995). Remembering to forget: Memory, history, National Identity in postwar East-Central Europe. Representations, 49, 72-96.

Esquith, S. L. (2013). Reframing the responsibilities of bystanders through film. Political Theory, 41(1), 33-60.

Forecki, P. (2010). Od "Shoah" do "Strachu". Spory o polsko-żydowską przeszłość i pamięć w debatach publicznych. Poznań: Wydawnictwo Poznańskie.

Friedman, J. (1994). Cultural Identity and Global Process. London: SAGE.

Friedrich, K.-P. (2005). Collaboration in a "land without a quisling": Patterns of cooperation with the Nazi German occupation regime in Poland during world war II. Slavic Review, 64(4), 711-746.

Giddens, A. (1990). The Consequences of Modernity. Cambridge: Polity Press.

Giddens, A. (1994). Living in a Post-Traditional Society. In U. Beck, A. Giddens, \& S. Lash (Eds.), Reflexive Modernization: Politics, Tradition and Aesthetics in the Modern Social Order. Stanford: Stanford University Press.

Götz, A., \& Heim, S. (2002). Architects of Annihilation: Auschwitz and the Logic of Destruction. London: Weidenfeld and Nicolson.

Grabowski, J. (2013). Hunt for the Jews: Betrayal and Murder in German-Occupied Poland. Bloomington: Indiana University Press.

Gross, J. T. (2001). Neighbors: The Destruction of the Jewish Community in Jedwabne, Poland. Princeton: Princeton University Press.

Halbwachs, M. (1992). On Collective Memory. Edited, Translated, and with an Introduction by Lewis A. Coser. Chicago and London: The University of Chicago Press.

Hamilton, M. (2001). The Sociology of Religion. Theoretical and Comparative perspectives (2nd ed.). London and New York: Routledge.

Himka, J.-P. (2008). Obstacles to the integration of the Holocaust into post-communist East European historical narratives. Canadian Slavonic Papers/Revue canadienne des slavistes, L(3-4), 359-372.

Hoffman, E. (2004). After Such Knowledge. A Meditation on the Aftermath of the Holocaust. London: Vintage.

Huyssen, A. (2000). Present pasts: Media, politics, amnesia. Public Culture, 12(1), 21-38.

Judt, T. (2005). Postwar. A History of Europe since 1945. New York: Penguin.

Kansteiner, W. (2002). Finding meaning in memory: A methodological critique of collective memory studies. History and Theory, 41(2), 179-197.

Kapralski, S. (1999). People of Different Times. In S. Kapralski (Ed.), The Jews in Poland (Vol. 2). Kraków: Judaica Foundation.

Kubik, J. (1994). The Power of Symbols against the Symbols of Power. The Rise of Solidarity and the Fall of State Socialism in Poland. University Park, Pennsylvania: The Pennsylvania State University Press.

Kucia, M. (2016). The Europeanization of Holocaust memory and Eastern Europe. East European Politics and Societies and Cultures, 30(1), 97-119.

Kwiatkowski, P. T. (2010). II wojna światowa jako doświadczenie narodowe. In P. T. Kwiatkowski, L. M. Nijakowski, B. Szacka \& A. Szpociński (Eds.), Między codziennościq a wielkq historiq. Druga wojna światowa w pamięci zbiorowej społeczeństwa polskiego. Gdańsk-Warszawa: Wydawnictwo Naukowe SCHOLAR.

LaCapra, D. (2001). Writing History, Writing Trauma. Baltimore: The Johns Hopkins University Press.

Lawson, T. (2010). Debates on the Holocaust. Manchester: Manchester University Press.

Leder, A. (2014). Prześniona rewolucja. Ćwiczenie z logiki historycznej. Warszawa: Wydawnictwo Krytyki Politycznej.

Levy, D., \& Sznaider, N. (2002). Memory unbound: The Holocaust and the formation of cosmopolitan memory. European Journal of Social Theory, 5(1), 87-106.

Levy, D., \& Sznaider, N. (2006). The Holocaust and Memory in the Global Age. Transl. by Assenka Oksiloff. Philadelphia: Temple University Press.

Levy, D., \& Sznaider, N. (2007). Memories of Europe: cosmopolitanism and its others. In C. Rumford (Ed.), Cosmopolitanism in Europe (pp. 158-177). Liverpool: Liverpool University Press.

Mälksoo, M. (2014). Criminalizing communism: Transnational Mnemopolitics in Europe. International Political Sociology, 8(1), 82-99.

Mälksoo, M. (2015). "Memory must be defended": Beyond the politics of mnemonical security. Security Dialogue, 46(3), 221-237.

Michlic, J. (2012). The Jedwabne Debate: Reshaping Polish National Mythology. In R. S. Wistrich (Ed.), Holocaust Denial: The Politics of Perfidy. Berlin and Boston: De Gruyter. 
Mouffe, C. (2000). Deliberative Democracy or Agonistic Pluralism ()Reihe Politikwissenschaft / Political Science Series 72. Vienna: Department of Political Science, Institute for Advanced Studies (IHS).

Muzaini, H., \& Yeoh, B. S. A. (2005). War landscapes as "battlefields" of collective memories: Reading the Reflections at Bukit Chandu, Singapore. Cultural Geographies, 12(3), 345-365.

Novick, P. (2001). The Holocaust and Collective Memory. The American Experience. Bloomsbury: London.

Pearce, S. C. (2011). Delete, restart, or rewind? Post-1989 public memory work in East-Central Europe. Sociology Compass, 5(4), 256-272.

Pinto, D. (1996). Pięćdziesiąt lat po Zagładzie: konieczność budowania nowej pamięci polsko-żydowskiej. In Pamięć żydowska, pamięć polska. Kraków: Instytut Francuski w Krakowie and C\&D International Editors.

Pohl, D. (2004). Contemporary Responses to the Shoah in Germany and Eastern Europe. In K. Kwiet, \& J. Matthäus (Eds.), Contemporary Responses to the Holocaust. Westport and London: Praeger.

Probst, L. (2003). Founding myths in Europe and the role of the Holocaust. New German Critique, 45-58.

Ricoeur, P. (2004). Memory, History, Forgetting. Trans. Kathleen Blamey and David Pellauer. Chicago: University of Chicago Press.

Roskies, D. K., \& Roskies, D. G. (1975). The Shtetl Book: An Introduction To East European Jewish Life And Lore. New York: Ktav Publishing House.

Rothberg, M. (2009). Multidirectional Memory: Remembering the Holocaust in the Age of Decolonization. Stanford: Stanford University Press.

Schütz, A. (1962). Common-Sense and Scientific Interpretation of Human Action. In A. Schütz (Ed.), Collected Papers (Vol. 1: The Problem of Social Reality). The Hague: Nijhoff.

Scott, J. (2011). Conceptualising the Social World. Principles of Sociological Analysis. Cambridge: Cambridge University Press.

Sennett, R. (1998). Disturbing Memories. In P. Fara, \& K. Patterson (Eds.), Memory. Cambridge: Cambridge University Press.

Sewell, W. H. Jr. (2005). Logics of History. Social Theory and Social Transformation. Chicago: The University of Chicago Press.

Shafir, M. (2004). Denying the Holocaust where it Happened. Post-Communist East Central Europe and the Shoah. In R. Lentin (Ed.), Re-presenting the Shoah for the Twenty-First Century. New York and Oxford: Berghahn Books.

Steinlauf, M. C. (1997). Bondage to the Dead. Poland and the Memory of the Holocaust. Syracuse: Syracuse University Press.

Stier, O. B. (2003). Committed to Memory. Cultural Mediations of the Holocaust. Amherst: University of Massachusetts Press.

Stone, D. (2010). Beyond the Mnemosyne Institute: The Future of Memory after the Age of Commemoration. In R. Crownshaw, J. Kilby, \& A. Rowland (Eds.), The Future of Memory. New York and Oxford: Berghahn Books.

Sztompka, P. (2000). Cultural trauma. The other face of social change. European Journal of Social Theory, 3(4), 449-466.

Terdiman, R. (1993). Present Past. Modernity and the Memory Crisis. Ithaca and London: Cornell University Press.

Tismaneanu, V. (1998). Fantasies of Salvation. Democracy, Nationalism, and Myth in Post-Communist Europe. Princeton, New Jersey: Princeton University Press.

Tokarska-Bakir, J. (2004). Rzeczy mgliste. Eseje i studia. Sejny: Pogranicze.

Tokarska-Bakir, J. (2008). Legendy o krwi. Antropologia przesądu. Warszawa: Wydawnictwo W.A:B.

Törnqvist-Plewa, B. (2005). The Jedwabne Killings - A Challenge for Polish Collective Memory. In K.-G. Karlsson, \& U. Zander (Eds.), Echoes of the Holocaust. Historical Cultures in Contemporary Europe. Lund: Nordic Academic Press.

Trouillot, M.-R. (1995). Silencing the Past. Power and the Production of History. Boston: Beacon Press.

Tyndall, A. (2004). Memory, Authenticity and Replication of the Shoah in Museums. Defensive Tools of the Nation. In R. Lentin (Ed.), Re-presenting the Shoah for the Twenty-First Century. New York-Oxford: Berghahn Books.

Uffelmann, D. (2013). Theory as Memory Practice: The Divided Discourse on Poland's Postcoloniality. In U. Blacker, A. Etkind, \& J. Fedor (Eds.), Memory and Theory in Eastern Europe. New York: Palgrave Macmillan.

Vinitzky-Seroussi, V., \& Teeger, C. (2010). Unpacking the unspoken: Silence in collective memory and forgetting. Social Forces, 88(3), 1103-1112.

Waller, J. (2002). Becoming Evil. How Ordinary People Commit Genocide and Mass Killing. Oxford: Oxford University Press.

Weinbaum, L. (2001). The Struggle for Memory in Poland. Auschwitz, Jedwabne and Beyond. Jerusalem: Institute of the World Jewish Congress.

White, H. C. (1992). Identity and Control. A Structural Theory of Social Action. Princeton: Princeton University Press.

Yerushalmi, Y. H. (1996). Zakhor: Jewish History and Jewish Memory. Seattle: University of Washington Press. 
How to cite this article: Kapralski S. The Holocaust: Commemorated but not remembered? Post-colonial and post-traumatic perspectives on the reception of the Holocaust memory discourse in Poland. J Hist Sociol. 2018;31:e48-e65. https://doi.org/10.1111/johs.12165 